\title{
Uncertainty of Cash Flow and Corporate Innovation
}

\author{
Jinchi Qu \\ Management School, Jinan University, Guangzhou, China \\ Email: qujay555@163.com
}

How to cite this paper: $\mathrm{Qu}, \mathrm{J}$. C. (2020) Uncertainty of Cash Flow and Corporate Innovation. Modern Economy, 11, 881-893. https://doi.org/10.4236/me.2020.114066

Received: February 25, 2020

Accepted: April 18, 2020

Published: April 21, 2020

Copyright (C) 2020 by author(s) and Scientific Research Publishing Inc. This work is licensed under the Creative Commons Attribution International License (CC BY 4.0).

http://creativecommons.org/licenses/by/4.0/

\begin{abstract}
Facing the uncertainty of internal and external environment, how to reasonably manage the cash flow and improve the competitiveness has become a hot research topic. Based on the theory of financing priority, liquidity preference and financing constraint, this paper analyzes the relationship between cash flow uncertainty and enterprise innovation, and verifies the effect of cash flow uncertainty on enterprise innovation. In addition, government subsidies and senior management shareholding are added into the original model as moderating variables to explore whether external factors of enterprises such as government subsidies and internal factors of enterprises such as governance structure will have an impact on the relationship between cash flow uncertainty and enterprise innovation.
\end{abstract}

\section{Keywords}

Enterprise Innovation, Uncertainty of Cash Flow, Government Subsidies, Corporate Governance Structure

\section{Introduction}

Today, companies face a complex and volatile environment. Firstly, with the continuous development of economic globalization, national and local policies change frequently, and the macro environment of enterprises constantly fluctuates. Secondly, the industry and development stage of the enterprise itself is full of high uncertainty, and it is difficult for the enterprise to predict the behavior of competitors, suppliers and customers. At the same time, the internal factors of the enterprise, such as operation management, strategic management and other aspects, have certain risks, which increase the variables of the future development of the enterprise. The constant changes of these macro and micro factors increase the risk degree of the enterprise to some extent, and these un- 
certainties are ultimately reflected in the volatility of cash flow. Therefore, researchers take the uncertainty of cash flow as a comprehensive reflection of the current internal and external environment of enterprises, and study the causes and possible consequences of the uncertainty of cash flow.

At the time of China's economic transformation, increasing the intensity of research and development and improving the independent innovation capability of enterprises have become the primary national goal and major challenges faced by enterprises. As an important driving factor for the survival and development of the country and enterprises, innovation has gradually become a strategic task of China's economic transformation. For enterprise how to use industrial upgrading from cost effectively leading enterprises transformation and upgrading of innovative enterprises, as well as in industrial upgrading, how to integrate the internal resources and external resources, how to effectively use the enterprise internal and external environmental fluctuations, improve their ability to adapt and strain capacity, and promote enterprise innovation to be a successful enterprise must be thinking of problem. Cash flow is an important source of capital for enterprise innovation, and its health status is an important guarantee for the long-term development of enterprise innovation activities. This paper attempts to explore the relationship between the uncertainty of cash flow and the existence of enterprise innovation, and at the same time studies the role played by government subsidies and executive shareholding, and further subdivides the characteristics of corporate governance structure for group test. This paper reveals the influence mechanism of cash flow uncertainty on enterprise innovation and the role of government and internal factors in the process of enterprise innovation.

\section{Literature Review}

\subsection{Literature Review on Cash Flow Uncertainty and Enterprise Innovation}

The uncertainty of cash flow refers to the fluctuation level of cash flow. On the one hand, it represents the stability and predictability of cash flow, on the other hand, it also represents the future development space and the possibility of rising performance of the enterprise. Both the external macro environment and the internal micro environment will affect the uncertainty of cash flow. Hackbarth et al. (2006) pointed out that the uncertainty of cash flow from the macroscopic environment and microcosmic environment integrated force, due to changes in macro aspect mainly embodied in the economic factors of uncertainty, micro level refers to the enterprise itself characteristics caused by the fluctuation, the resulting combined effect show the cash flow volatility, will affect the delivery and the firm's difference.

Therefore, many scholars have studied the relationship between macro and micro environment uncertainty and investment behavior of enterprises. At the macro level, Shen et al. (2012) specifically defined uncertainty as environmental 
uncertainty, and from the perspective of managers, discussed the adverse impact of capital fluctuations caused by environmental uncertainty on investment efficiency. The study points out that environmental uncertainty makes it more difficult for managers to evaluate investment projects, which leads them to reject high-risk investment projects and make relatively prudent investment decisions. At the same time, in order to cope with the future cash flow fluctuations, managers often need to balance the current and future investment expenditures, and a large amount of cash is retained in the enterprise, rather than used for external capital appreciation projects, which leads to the decrease of enterprise capital utilization efficiency, and then the insufficient allocation of investment project resources. Chen et al. (2016) specifically defined uncertainty as policy uncertainty, and investigated how the change of party secretary of local officials affects the innovation behavior of enterprises. The result shows that the policy uncertainty caused by the change of party secretary will reduce the innovation efficiency of enterprises. Zhang \& Liu (2018) found that no matter whether the financing constraints of enterprises are high or low, the increase of economic policy uncertainty will lead to the decline of enterprise investment. In particular, the reduction of leverage ratio and the upward adjustment of cash holdings are significantly weaker in low-constrained enterprises than in high-constrained enterprises.

As one of the important investment projects, innovation activities are more correlated with cash flow fluctuation level. Using the data of Chinese listed companies, Ju (2013) found that in terms of innovation financing, internal capital is the main financing channel for enterprises to invest in innovation. External financing has different effects on different types of enterprises with different property rights. Bank loan is an important financing method for innovation investment of central state-owned holding companies, but it has little contribution to other types of enterprises. Based on the macro environment faced by listed companies in China, Qin \& Zhang (2016) focused on the financing constraints of R\&D activities around the macro level of uncertainty, and found that the cash flow fluctuations caused by macroeconomic changes often lead to the obstruction of R\&D activities. Malherbe (2014) found that the future market liquidity shortage makes cash holding more attractive. Therefore, enterprises tend to increase cash holding to cope with possible future cash flow fluctuations.

\subsection{Government Subsidies, Executive Shareholding and Enterprise Innovation}

At present, there have been literature studies on the impact of government subsidies on enterprise innovation input, and there are mainly two conclusions: one is that government subsidies have incentive effect on enterprise innovation input, and the other is that government subsidies have crowding out effect on enterprise innovation input. Xie et al. (2009) found in their research that government subsidies stimulated the R\&D expenditure of enterprises. Second, from the perspective of information transmission theory, the government subsidizes the enter- 
prises, which indicates that the enterprises meet the corresponding conditions and have the qualification of "innovation-oriented enterprises", which is more conducive to the external financing of enterprises, improves the enthusiasm of enterprises to carry out innovative projects, and increases the confidence of enterprises to invest in innovation. On the contrary, Kothari et al. (2002) study found that the existence of government subsidies make enterprise innovation activities in the process, from the enterprise's own investment reduced, government subsidies are only alternative to the enterprise innovation input before. According to An et al. (2009), the research results of domestic scholars are as follows: with the increase of government subsidies, the overall investment of enterprises in innovation actually decreases. It can be seen that the existence of government subsidies can't well correct the phenomenon of "market failure".

On the aspect of executive shareholding, Richardson (2006) analyzed the interference of corporate equity incentive mechanism on corporate investment behavior, and believed that the company's equity incentive mechanism to the management could better regulate the abnormal investment behavior of corporate managers and avoid the phenomenon of low $\mathrm{R} \& \mathrm{D}$ investment. Lin et al. (2011) used data from 1088 private enterprises in China from 2000 to 2002 to empirically study the correlation between corporate executive motivation and corporate innovation. The results show that the incentive mechanism of executive compensation significantly increases the input and output of enterprise innovation. Hellmann and Thiele (2011) tested the correlation between the equity incentive of corporate executives and enterprise innovation by constructing a multi-task mathematical model, and finally concluded that the equity incentive of corporate executives can effectively promote enterprise innovation. Tien \& Chen (2012) investigated 107 listed companies in the United States and found that neither long-term equity incentive nor short-term compensation incentive had a significant effect on the innovation investment of enterprises.

\section{Theoretical Analysis and Research Hypothesis}

This paper proposes relevant research hypotheses through theoretical analysis and literature review.

\subsection{Impact of Cash Flow Uncertainty on Enterprise Innovation}

The operation and investment of enterprises need capital support, and the different allocation of capital sources has advantages and disadvantages, so that enterprises are faced with the balance between capital and cost in the selection process. On the basis of information asymmetry theory, this paper analyzes the choice of financing mode. Enterprise innovation fund mainly comes from internal created and accumulated cash flow and external financing, according to the optimal sequence financing theory, enterprise in the process of raising money, usually preferred internal capital channel, namely the priority to use the business activities of the total funds for production and investment, when internal funds 
in shortage, will only by attracting external funding provider, in turn, get their financial support. As an important source of capital, cash flow has an important influence on the internal and external financing of enterprise innovation. Firstly, the uncertainty of cash flow squeezes the R\&D investment of enterprises by acting on the internal financing situation. Cash flow is the main form of endogenous financing for innovation activities. The long-term characteristics of $R \& D$ investment itself make it more demanding for the sustainability of internal capital. Therefore, internal cash flow is the main source of capital for enterprise innovation, and its stability has an important impact on enterprise innovation. The uncertainty of cash flow will make it more difficult for enterprises to predict the future capital situation, so it is difficult to effectively guarantee the long-term internal capital, and they will have negative delight in the research and development activities mainly relying on self-accumulated capital, thus inhibiting the improvement of innovation ability. At the same time, based on the theory of liquidity preference, people tend to hold by rights and money way to obtain higher liquidity in the future period, this approach to a great extent from the risk prevention of motivation in the future, is that by holding more than average amount of the reserve funds to reduce the possibility of the future may be in financial difficulties. Based on the above theoretical analysis, hypothesis 1 is proposed in this paper:

Hypothesis 1: under other conditions unchanged, the uncertainty of cash flow has an inhibiting effect on enterprise innovation.

\subsection{Impact of Government Subsidies on Cash Flow Uncertainty and Enterprise Innovation}

Government subsidy has certain incentive effect. Li et al. (2013) study found that the government subsidies can significantly improve the innovation investment of Chinese listed companies, most times the influence of equity financing, debt financing is not obvious. The government subsidies to creditor's rights financing and the regulation of company innovation investment plays a significant role in the relationship between the effect of government subsidy can "stimulus" through debt financing of listed companies to improve innovation investment company. Therefore, based on the above theoretical analysis, this paper put forward the hypothesis 2 :

Hypothesis 2: government subsidies can positively adjust the inhibitory effect of cash flow uncertainty on enterprise innovation.

\subsection{Impact of Senior Management Shareholding on Cash Flow Uncertainty and Enterprise Innovation}

Based on Schumpeter's theory of innovation, executive group is the prerequisite and dynamic manifestation of innovation activities and plays an important role in the field of innovation upgrading. The internal governance mechanism of the company will affect the innovation motivation of the executives, and the share- 
holding of the executives is conducive to the promotion of enterprise innovation. Zhou \& Xue (2008) found that the number of shares held by the general manager of the company was significantly positively correlated with the $R \& D$ investment of the company. High uncertainty of cash flow not only means high risk, but also includes the possibility of future development and growth. When executives own more shares, they will pay more attention to the long-term development of the enterprise like other shareholders. Research and development activities and technological innovation are important for the long-term development of enterprises. Based on this, this paper proposes hypothesis 3 :

Hypothesis 3: executive shareholding can positively adjust the inhibitory effect of cash flow uncertainty on enterprise innovation.

This paper uses statistical software STATA14 to establish a multiple linear regression model to verify hypotheses.

\section{Research Design}

\subsection{Sample Selection and Data Sources}

This paper takes the a-share listed companies in Shanghai and Shenzhen from 2009 to 2018 as the research object. Since the uncertainty of cash flow needs to be measured by the data volatility of the last three years, this paper selects the data from 2007 to 2018 as the sample data to calculate the uncertainty of cash flow. The sample data came from the CSMAR database. Considering the particularity of the industry and the company, and in order to avoid the possible adverse impact of interference factors on the research, the sample data were screened as follows: 1) excluding financial and insurance enterprises; 2) remove ST and ${ }^{*}$ ST company; 3) samples with missing data or significant anomalies were excluded. Finally, 6037 data samples were obtained. In this paper, the sample industry was subdivided by using the CSRC classification standard, and the sample data was empirically analyzed by using STATA14. The data was collated using Excel.

\subsection{Variable Design}

Since this paper mainly studies the input process of innovation activities, this paper chooses the research and development intensity for enterprise innovation. To measure, enterprise innovation input is measured by the proportion of $R \& D$ investment in total assets, expressed as $\mathrm{RD}$, and the logarithm of the number of patent applications is used in the robustness test to measure enterprise innovation. In this paper, the standard deviation of the company's net cash flow in the recent three years is used as the measurement index of the uncertainty of the company's cash flow, which is expressed by OCF_sd. This paper USES the financial statement "government subsidy" to measure the government subsidy, and the variable name is GS. Based on the signal theory, this paper studies the impact of government subsidy on the relationship between cash flow uncertainty and enterprise innovation. Therefore, this variable is set as a dummy variable. If 
there is no government subsidy in the previous period, GS is 0 . The equity property variable SOE in this paper is a dummy variable. In this paper, the number of senior executives' shareholding/total number of shares is used to measure the variable of senior executives' shareholding. In this paper, based on the existing literature on the impact of enterprise innovation, on the basis of explanatory variables to add other control variables that may affect the explained variables. The definitions and measures of variables in this paper are summarized in table form as shown in the following Table 1.

\subsection{Model Design}

For hypothesis 1 , the following regression model is constructed in this paper to test the impact of cash flow uncertainty on enterprise innovation. Model (1) is as follows:

$$
\begin{aligned}
\mathrm{RD}_{i, t}= & \propto_{0}+\propto_{1} \mathrm{OCF}_{-} \mathrm{sd}_{i, t}+\propto_{2} \mathrm{SIZE}_{i, t}+\propto_{3} \mathrm{LEV}_{i, t}+\propto_{4} \mathrm{ROA}_{i, t}+\propto_{5} \mathrm{TURN}_{i, t} \\
& +\propto_{6} \mathrm{TBQ}_{i, t}+\propto_{7} \mathrm{CI}_{i, t}+\propto_{8} \mathrm{AF}_{i, t}+\sum \text { year }+\sum \text { industry }+\varepsilon
\end{aligned}
$$

\begin{tabular}{|c|c|c|c|}
\hline Variable types & $\begin{array}{l}\text { Variable } \\
\text { symbol }\end{array}$ & $\begin{array}{l}\text { The variable } \\
\text { name }\end{array}$ & Variable definitions \\
\hline $\begin{array}{l}\text { Explained } \\
\text { variable }\end{array}$ & $\mathrm{RD}$ & $\begin{array}{l}\text { Enterprise } \\
\text { innovation }\end{array}$ & $\mathrm{R} \& \mathrm{D}$ investment/total assets \\
\hline $\begin{array}{l}\text { Explanatory } \\
\text { variables }\end{array}$ & OCF_sd & $\begin{array}{l}\text { Cash flow } \\
\text { uncertainty }\end{array}$ & $\begin{array}{l}\text { Standard deviation of net cash flow from operating } \\
\text { activities in year t- } 2 \text { to year } \mathrm{t}\end{array}$ \\
\hline \multirow[t]{2}{*}{$\begin{array}{l}\text { Adjust the } \\
\text { variable }\end{array}$} & GS & $\begin{array}{l}\text { Government } \\
\text { subsidies }\end{array}$ & $\begin{array}{l}\text { As a dummy variable, if the previous government } \\
\text { subsidy of an enterprise is not } 0 \text {, then GS is } 1 \text {. If the } \\
\text { enterprise has no government subsidy in the } \\
\text { previous period, GS is } 0\end{array}$ \\
\hline & ES & $\begin{array}{l}\text { Executives at } \\
\text { stake }\end{array}$ & $\begin{array}{l}\text { Number of shares held by senior executives/total } \\
\text { number of shares }\end{array}$ \\
\hline \multirow{9}{*}{$\begin{array}{l}\text { Control } \\
\text { variables }\end{array}$} & The SIZE & $\begin{array}{l}\text { The enterprise } \\
\text { scale }\end{array}$ & $\begin{array}{l}\text { The natural logarithm of the total number of } \\
\text { employees in an enterprise }\end{array}$ \\
\hline & LEV & $\begin{array}{l}\text { Asset-liability } \\
\text { ratio }\end{array}$ & Total liabilities at year end/total assets at year end \\
\hline & ROA & $\begin{array}{l}\text { Return on total } \\
\text { assets }\end{array}$ & Net profit/total assets \\
\hline & TURN & $\begin{array}{l}\text { Total asset } \\
\text { turnover }\end{array}$ & Operating income/total assets \\
\hline & TBQ & Tobin Q value & Market value/total assets \\
\hline & CI & Capital intensity & Net fixed assets/total assets \\
\hline & $\mathrm{AF}$ & Analyst focus & $\begin{array}{l}\text { The natural log of the number of analysts (teams) } \\
\text { who have tracked the company }\end{array}$ \\
\hline & YEAR & Annual dummy & $\begin{array}{l}\text { When the enterprise is in that year, the value is } 1 \text {; } \\
\text { Otherwise it's } 0\end{array}$ \\
\hline & IND & Industry dummy & $\begin{array}{l}12 \text { industry dummy variables, when the enterprise } \\
\text { is in the industry, the value is } 1 \text {; Otherwise it's } 0\end{array}$ \\
\hline
\end{tabular}

Table 1. Main variables definition table.

*Data from CSMAR database. 
In this model, explanatory variables cash flow uncertainty and other relevant control variables are added. According to the previous analysis, cash flow uncertainty exerts a inhibitory effect on enterprise innovation by crowding out innovation investment and generating external financing constraints, so the expected coefficient is negative for $\propto_{1}$.

For hypothesis 2, dummy variables of government subsidies are added on the basis of regression model (1) to test the impact of government subsidies on the relationship between cash flow uncertainty and enterprise innovation. Regression model (2) is as follows:

$$
\begin{aligned}
\mathrm{RD}_{i, t}= & \propto_{0}+\propto_{1} \text { OCF_sd }{ }_{i, t}+\propto_{2} \mathrm{GS}_{i, t}+\propto_{3} \text { OCF_sd }_{i, t} * \mathrm{GS}_{i, t} \\
& +\propto_{4} \mathrm{SIZE}_{i, t}+\propto_{5} \mathrm{LEV}_{i, t}+\propto_{6} \mathrm{ROA}_{i, t}+\propto_{7} \mathrm{TURN}_{i, t} \\
& +\propto_{8} \mathrm{TBQ}_{i, t}+\propto_{9} \mathrm{CI}_{i, t}+\propto_{10} \mathrm{AF}_{i, t}+\sum \text { year }+\sum \text { industry }+\varepsilon
\end{aligned}
$$

The expected coefficient is negative for $\propto_{3}$.

For hypothesis 3, the variables of senior management shareholding are added on the basis of the regression model (1) to test the impact of senior management shareholding on the relationship between cash flow uncertainty and enterprise innovation. The regression model (2) is as follows:

$$
\begin{aligned}
\mathrm{RD}_{i, t}= & \propto_{0}+\propto_{1} \mathrm{OCF}_{-} \mathrm{sd}_{i, t}+\propto_{2} \mathrm{ES}_{i, t}+\propto_{3} \mathrm{OCF}_{-} s d_{i, t} * \mathrm{ES}_{i, t} \\
& +\propto_{4} \mathrm{SIZE}_{i, t}+\propto_{5} \mathrm{LEV}_{i, t}+\propto_{6} \mathrm{ROA}_{i, t}+\propto_{7} \mathrm{TURN}_{i, t} \\
& +\propto_{8} \mathrm{TBQ}_{i, t}+\propto_{9} \mathrm{CI}_{i, t}+\propto_{10} \mathrm{AF}_{i, t}+\sum \text { year }+\sum \text { industry }+\varepsilon
\end{aligned}
$$

The expected coefficient is negative for $\propto_{3}$.

\section{Empirical Analysis}

\subsection{Descriptive Statistics}

The descriptive statistical results of the main variables in this paper are shown in Table 2.

Table 2. Descriptive statistical results.

\begin{tabular}{ccccccccc}
\hline Variable & Size & Mean & SD & Min & P25 & P50 & P75 & Max \\
\hline RD & 6037 & 0.02 & 0.026 & 0 & 0.005 & 0.016 & 0.027 & 1.04 \\
OCF sd & 6037 & 0.081 & 0.131 & 0 & 0.027 & 0.051 & 0.092 & 3.778 \\
GS & 6037 & 0.876 & 0.329 & 0 & 1 & 1 & 1 & 1 \\
ES & 6037 & 0.024 & 0.086 & 0 & 0 & 0 & 0.003 & 0.999 \\
SIZE & 6037 & 8.238 & 1.184 & 3.664 & 7.424 & 8.208 & 8.954 & 13.165 \\
LEV & 6037 & 0.476 & 0.189 & 0.018 & 0.334 & 0.485 & 0.62 & 1.352 \\
ROA & 6037 & 0.039 & -0.556 & 0.556 & 0.012 & 0.032 & 0.061 & 0.384 \\
TURN & 6037 & 0.718 & 0.58 & 0.027 & 0.405 & 0.6 & 0.856 & 10.586 \\
TBQ & 6037 & 2.012 & 1.533 & 0.153 & 1.173 & 1.569 & 2.288 & 31.4 \\
CI & 6037 & 0.24 & 0.161 & 0 & 0.116 & 0.207 & 0.336 & 0.92 \\
AF & 6037 & 1.622 & 1.163 & 0 & 0.693 & 1.792 & 2.565 & 4.331 \\
\hline
\end{tabular}


Showing in Table 2, the RD reached an average of 0.02 , with a median of 0.016 . The proportion of $R \& D$ investment was generally small, with the upper quartile being 0.005 and the lower quartile being 0.027 . There is a significant difference in the intensity among enterprises, and the enthusiasm of enterprises for innovation activities is quite different. The average level of uncertainty in operating cash flow of an enterprise is 0.081 , the median is 0.051 , and the standard deviation is 0.131 . The cash flow of operating activities of enterprises generally fluctuates to varying degrees, and the degree of fluctuation shows a large difference. The average executive shareholding ratio reached 0.024 . The upper quartile is 0 and the lower quartile is 0.003 . There is a certain difference in the variable data. Among the control variables, the average value of the scale of the enterprises is 8.238 , and the median is 8.208 . The data of the scale variables are evenly distributed. The average asset-liability ratio is 0.476 , the upper quartile is 0.334 , and the lower quartile is 0.62 . It can be seen that the level of corporate debt basically reaches $50 \%$ of total assets, but there are still differences in capital structure among enterprises. The Tobin $\mathrm{Q}$ value averages 2.012, the upper quartile is 1.173 , and the lower quartile is 2.288 . There is a certain difference in corporate market valuation and development potential. The average capital intensity is 0.24 , and the median is 0.207 . It can be seen that the proportion of fixed assets in enterprises accounts for about one fifth of the total assets of enterprises. The average and median return on total assets are 0.039 and 0.032 , and the average value of total asset turnover is 0.718 , with a median of 0.6 . It can be seen that corporate profitability and operating capacity are generally good, and the data are evenly distributed. The mean and median of the attention variables of the analysts were 1.622 and 1.792 , respectively, and the data were evenly distributed.

\subsection{Regression Analysis of Cash Flow Uncertainty on Enterprise Innovation}

The regression results of model (1) are shown in Table 3.

As can be seen from Table 3, the coefficient of the uncertainty variable of cash flow is negative and is significant at the $5 \%$ level, indicating that the uncertainty of cash flow has an obvious negative impact on enterprise innovation, and the uncertainty of cash flow is not conducive to the development of enterprise innovation. The hypothesis 1 proposed in this paper is verified, that is, the uncertainty of cash flow will significantly inhibit the innovation investment of enterprises.

\subsection{Regulating Effects of Government Subsidies and Senior Executives' Shareholding}

The regression results of model (2) and (3) are shown in Table 4.

As shown in column 2 of Table 4, the coefficient of cash flow uncertainty variable is negative and is significant at the $1 \%$ level. The coefficient of government subsidy variable is positive and is significant at the $1 \%$ level, indicating that gov- 
ernment subsidy promotes enterprise innovation to some extent. The coefficient of the cross term between the government subsidy variable and the enterprise innovation variable is greater than 0 , and it is significant at the level of $5 \%$, indicating that the government subsidy can positively adjust the inhibition effect of cash flow uncertainty on enterprise innovation. Hypothesis 2 proposed in this paper has been verified. As shown in column 3 of Table 4, the coefficient of cash flow uncertainty variable is negative and is significant at the $10 \%$ level. The coefficient of the variable of executive shareholding is positive, and is significant at the level of $5 \%$, indicating that executive shareholding promotes enterprise innovation to a certain extent. The coefficient of the cross term between the variables of executive ownership and enterprise innovation is greater than 0 and is significant at the $5 \%$ level, indicating that executive ownership can positively adjust the inhibitory effect of cash flow uncertainty on enterprise innovation. Hypothesis 3 proposed in this paper has been verified.

\section{Conclusion}

Starting from the comprehensive index of cash flow uncertainty, this paper studies the relationship between cash flow uncertainty and enterprise innovation. The results show that the risk brought by the uncertainty of cash and flow is higher than the opportunity, and its impact on enterprise innovation is mainly reflected in the inhibiting effect, that is, the greater the uncertainty of cash flow, the more inclined the enterprise is to reduce the innovation input, thus inhibiting the improvement of innovation ability. However, government subsidy and senior management shareholding can alleviate the adverse impact of cash flow uncertainty on enterprise innovation and promote enterprise innovation.

Table 3. Regression results of model (1).

\begin{tabular}{|c|c|c|c|c|}
\hline \multirow{2}{*}{ Variable } & \multicolumn{4}{|c|}{$\mathrm{RD}$} \\
\hline & The coefficient of & $\mathrm{T}$ value & $P$ values & Significant \\
\hline OCF_sd & -0.005 & -2.21 & 0.027 & $* *$ \\
\hline The SIZE & 0.001 & 2.12 & 0.034 & $* *$ \\
\hline LEV & -0.009 & -4.59 & 0.000 & $* * *$ \\
\hline ROA & 0.005 & 0.77 & 0.442 & \\
\hline TURN & 0.005 & 8.64 & 0.000 & $* * *$ \\
\hline TBQ & 0.002 & 7.59 & 0.000 & $* * *$ \\
\hline $\mathrm{CI}$ & 0.000 & 0.04 & 0.965 & \\
\hline $\mathrm{AF}$ & 0.002 & 5.33 & 0.000 & $* * *$ \\
\hline Constant & -1.217 & -3.01 & 0.003 & $* * *$ \\
\hline Industry & \multicolumn{4}{|c|}{ Control } \\
\hline The annual & \multicolumn{4}{|c|}{ Control } \\
\hline Adj R-squared & \multicolumn{4}{|c|}{0.2578} \\
\hline $\mathrm{N}$ & \multicolumn{4}{|c|}{6037} \\
\hline
\end{tabular}


Table 4. Regression results of model (2) and model (3).

\begin{tabular}{|c|c|c|}
\hline \multirow{2}{*}{ Variable } & Model (2) & Model (3) \\
\hline & $\mathrm{RD}$ & $\mathrm{RD}$ \\
\hline \multirow{2}{*}{ OCF_sd } & $-0.0071^{* * *}$ & $-0.0049^{\star}$ \\
\hline & $(-2.84)$ & $(-1.93)$ \\
\hline \multirow{2}{*}{ GS } & $0.0032^{\star * *}$ & \\
\hline & $(2.97)$ & \\
\hline \multirow[t]{2}{*}{ GS_x_OCF_sd } & $0.5901^{* *}$ & \\
\hline & $(2.50)$ & \\
\hline \multirow[t]{2}{*}{ ES } & & $0.0035^{\star *}$ \\
\hline & & $(2.48)$ \\
\hline \multirow[t]{2}{*}{ ES_x_OCF_sd } & & $0.0201^{* *}$ \\
\hline & & $(2.31)$ \\
\hline \multirow{2}{*}{ The SIZE } & $0.0008^{* *}$ & $0.0009^{* *}$ \\
\hline & $(2.18)$ & (2.33) \\
\hline \multirow{2}{*}{ LEV } & $-0.0093^{* * *}$ & $-0.0093^{\star * \star}$ \\
\hline & $(-4.56)$ & $(-4.29)$ \\
\hline \multirow{2}{*}{ ROA } & 0.0054 & 0.0056 \\
\hline & $(0.82)$ & $(0.81)$ \\
\hline \multirow{2}{*}{ TURN } & $0.0053^{\star * *}$ & $0.0055^{\star * *}$ \\
\hline & $(8.66)$ & $(8.52)$ \\
\hline \multirow{2}{*}{ TBQ } & $0.0018^{\star * *}$ & $0.0019^{\star * *}$ \\
\hline & $(7.58)$ & $(7.57)$ \\
\hline \multirow{2}{*}{$\mathrm{CI}$} & 0.0000 & -0.0005 \\
\hline & $(0.01)$ & $(-0.20)$ \\
\hline \multirow{2}{*}{$\mathrm{AF}$} & $0.0017^{\star * *}$ & $0.0016^{\star * *}$ \\
\hline & (5.25) & $(4.71)$ \\
\hline \multirow{2}{*}{ Constant } & $-1.2581^{\star * \star}$ & $-0.8315^{\star}$ \\
\hline & $(-3.10)$ & $(-1.79)$ \\
\hline Industry & Control & Control \\
\hline The annual & Control & Control \\
\hline Adj R-squared & 0.2592 & 0.257 \\
\hline $\mathrm{N}$ & 6037 & 6037 \\
\hline
\end{tabular}

Based on the research contents and conclusions of this paper, the following Suggestions are put forward: at the government level, on the basis of maintaining the stability of economic policies, the positive role of macro-control on market fluctuations can be moderately strengthened; at the enterprise level, the first step is to strengthen the risk control of cash flow, maintain the stability of funds, 
and reasonably arrange cash holdings. Enterprises should establish a sound cash flow supervision system to strengthen the risk assessment and monitoring of cash flow.

This article proves the relationship between cash flow uncertainty and corporate innovation to a certain extent, and introduces government subsidies and senior management holdings adjustment variables to verify the adjustment effects it induces. However, this paper still has some limitations and deficiencies. This article uses the amount of government subsidies in the financial statements to measure government subsidies. It does not subdivide the types of government subsidies, and does not study the different impacts of different forms of government subsidies. This article mainly researches from the perspective of enterprise innovation investment, so it mainly focuses on the R\&D intensity of the enterprise, and studies the overall innovation ability of the enterprise from the perspective of innovation output in the robustness test. The research on the conversion between different industries is still not comprehensive enough. Therefore, for future research in this area, I hope to further expand the scope of enterprise innovation based on innovation input and output, and conduct a more comprehensive study of enterprise innovation, which may include innovation efficiency and other aspects. In terms of government subsidies, I hope to subdivide the forms of government subsidies to study the impact of different types of government subsidies. In addition, this article does not conduct further research on industry differences. Future research can be based on this industry to conduct more in-depth research on specific industries.

\section{Acknowledgements}

Time flies, the graduate life is coming to an end, in these three years, I want to thank my tutor and my family. It is they who give me guidance, help and love, so that I have the courage and determination to face every challenge.

\section{Conflicts of Interest}

The author declares no conflicts of interest regarding the publication of this paper.

\section{References}

An, T. L., Zhou, S. D., \& Pi, J. C. (2009). Incentive Effect of R\&D Subsidy on Chinese Enterprises' Independent Innovation. Economic Research, No. 10, 87-98.

Chen, D. Q., Jin, Y. L., \& Dong, Z. Y. (2016). Policy Uncertainty, Political Relevance and Enterprise Innovation Efficiency. Nankai Management Review, No. 4, 27-35.

Hackbarth, D., Miao, J., \& Morellec, E. (2006). Capital Structure, Credit Risk, and Macroeconomic Conditions. Journal of Financial Economics, 82, 519-550. https://doi.org/10.1016/j.jfineco.2005.10.003

Hellmann, T., \& Thiele, V. (2011). Incentives and Innovation: A Multitasking. American Economic Journal: Microeconomics, 3, 78-128. https://doi.org/10.1257/mic.3.1.78

Ju, X. S. (2013). Financing Source and Smoothing Mechanism of Innovation Investment 
of Chinese Listed Enterprises. World Economy, No. 4, 138-159.

Kothari, S. P., Laguerre, T. E., \& Leone, J. A. (2002). Capitalization versus Expensing: Evidence on the Uncertainty of the Future the Way the from Capital Expenditures versus R\&D Outlays. Review of Accounting Studies, 7, 355-382. https://doi.org/10.1023/A:1020764227390

Li, H. D., Tang, Y. J., \& Zuo, J. J. (2013). With Their Own Money or with Others' Money Innovation? Financial Research, No. 2, 170-183.

Lin, C., Lin, P., Song, F. M. et al. (2011). Managerial Incentives, CEO Characteristics and Corporate Innovation in China's Private Sector. Journal of Comparative Economics, 39, 176-190. https://doi.org/10.1016/j.jce.2009.12.001

Malherbe, F. (2014). Self-Serving Liquidity Dry-Ups. The Journal of Finance, 69, 947-970. https://doi.org/10.1111/jofi.12063

Qin, T. C., \& Zhang, T. G. (2016). Macroeconomic Fluctuations and Constraints on Enterprise R\&D Financing: Evidence from Chinese Listed Companies. Research and Development Management, 28, 2.

Richardson, S. (2006). Over-Investment of Free Cash Flow. Review of Accounting Studies, 11, 159-189. https://doi.org/10.1007/s11142-006-9012-1

Shen, H. H., Yu, P., \& Wu, L. S. (2012). State-Owned Equity, Environmental Uncertainty and Investment Efficiency. Economic Research, 47, 113-126.

Tien, C., \& Chen, C. (2012). Myth or Reality? Assessing the Moderating Role of CEO Compensation on the Momentum of Innovation in R\&D. Journal of the International Journal of Human Resource Management, 23, 2763-2784. https://doi.org/10.1080/09585192.2011.637059

Xie, W. M., Tang, Q. Q., \& Lu, S. S. (2009). Government R\&D Subsidy, Enterprise R\&D Expenditure and Independent Innovation: Empirical Evidence from Chinese Listed Companies. Financial Research, No. 6, 86-99.

Zhang, C. S., \& Liu, G. C. (2018). Investment and Financing Decision-Making Mechanism in China's Industrial Sector: Based on the Perspective of Economic Policy Uncertainty and Financing Constraint Heterogeneity. Economic Research, 53, 53-69.

Zhou, J., \& Xue, Y. Z. (2008). The Influence of Corporate Internal Governance Mechanism on R\&D Investment: An Empirical Study Based on General Manager Shareholding and Board Structure. Research and Development Management, 20, 1-9. 